\title{
Methane-suppressing effect of myristic acid in sheep as affected by dietary calcium and forage proportion
}

\author{
Andrea Machmüller*, Carla R. Soliva and Michael Kreuzer \\ Institute of Animal Science, Animal Nutrition, Swiss Federal Institute of Technology Zurich, \\ ETH Zentrum/LFW, CH-8092 Zurich, Switzerland
}

(Received 16 August 2002 - Revised 9 April 2003 - Accepted 13 May 2003)

\begin{abstract}
The efficiency of myristic acid $(14: 0)$ as a feed additive to suppress $\mathrm{CH}_{4}$ emissions of ruminants was evaluated under different dietary conditions. Six sheep were subjected to a $6 \times 6$ Latin square arrangement. A supplement of non-esterified 14:0 $(50 \mathrm{~g} / \mathrm{kg}$ DM) was added to two basal diets differing in their forage:concentrate values $(1: 1.5$ and $1: 0.5)$, which were adjusted to dietary Ca contents of 4.2 and $9.0 \mathrm{~g} /$ $\mathrm{kg}$ DM, respectively. Comparisons were made with the unsupplemented basal diets $(4 \cdot 2 \mathrm{~g} \mathrm{Ca} / \mathrm{kg} \mathrm{DM})$. The 14:0 supplementation decreased $(P<0.001)$ total tract $\mathrm{CH}_{4}$ release depending on basal diet type (interaction, $\left.P<0.001\right)$ and dietary Ca level $(P<0.05$, post hoc test). In the concentrate-based diet, $14: 0$ suppressed $\mathrm{CH}_{4}$ emission by 58 and $47 \%$ with 4.2 and $9 \cdot 0 \mathrm{~g} \mathrm{Ca} / \mathrm{kg} \mathrm{DM}$, respectively. The 14:0 effect was lower $(22 \%)$ in the forage-based diet and became insignificant with additional Ca. Myristic acid inhibited $(P<0.05)$ rumen archaea without significantly altering proportions of individual methanogen orders. Ciliate protozoa concentration was decreased $\left(P<0.05\right.$, post hoc test) by $14: 0$ only in combination with $9 \cdot 0 \mathrm{~g} \mathrm{Ca} / \mathrm{kg} \mathrm{DM}$. Rumen fluid $\mathrm{NH}_{3}$ concentration and acetate:propionate were decreased $(P<0 \cdot 05)$ and water consumption was lower $(P<0.01)$ with 14:0. The use of 14:0 had no clear effects on total tract organic matter and fibre digestion; this further illustrates that the suppressed methanogenesis resulted from direct effects against methanogens. The present study demonstrated that $14: 0$ is a potent $\mathrm{CH}_{4}$ inhibitor but, to be effective in $\mathrm{CH}_{4}$ mitigation feeding strategies, interactions with other diet ingredients have to be considered.
\end{abstract}

Methane: Myristic acid: Forage: Calcium

$\mathrm{CH}_{4}$ is currently recognised as the second most important greenhouse gas emitted from anthropogenic sources (Wuebbles \& Hayhoe, 2002). With the Kyoto protocol, there is a renewed interest to address mitigation of $\mathrm{CH}_{4}$ in animal agriculture. Annually worldwide, approximately $81 \mathrm{Tg} \mathrm{CH}_{4}$ are emitted from the gastrointestinal tracts of domestic ruminants and an additional $7 \mathrm{Tg} \mathrm{CH}_{4}$ originate annually from the manure of these animals (Johnson et al. 2000). Related to total anthropogenic $\mathrm{CH}_{4}$ emissions, this means that domestic ruminants are responsible for $25 \%$ of total anthropogenic $\mathrm{CH}_{4}$ emission (Khalil, 2000).

Concerning the $\mathrm{CH}_{4}$ produced within the rumen, one possible mitigation strategy is the use of dietary fats (Moss et al. 2000). It is known that medium-chain fatty acids (MCFA) have the potential to suppress rumen methanogenesis (Blaxter \& Czerkawski, 1966) and methanogens (Henderson, 1973). Ruminant diets containing coconut oil, a fat rich in the MCFA lauric acid (12:0) and myristic acid (14:0), decreased daily $\mathrm{CH}_{4}$ emissions in vitro (up to $88 \%$ suppression; Dong et al. 1997) and in vivo (up to $73 \%$ suppression; Machmüller \& Kreuzer, 1999); in vivo, coconut oil had no major adverse effects on nutrient digestion and utilisation of dietary energy or protein. However, as in vitro evaluations show, the extent of the $\mathrm{CH}_{4}$-suppressing effect of MCFA seems to depend on the kind of diet used. Coconut oil had a lower efficacy in suppressing $\mathrm{CH}_{4}$ when the fibrous proportion of the diet was increased (Machmüller et al. 2001). Additionally, the $\mathrm{CH}_{4}$-suppressing effect of non-esterified MCFA was lower when Ca was added to the diet (Machmüller et al. 2002). Comparing the effects of various non-esterified MCFA $(8: 0,10: 0$, $12: 0,14: 0)$ in vitro, $12: 0$ and $14: 0$ were identified to be most effective against rumen methanogens and methanogenesis (Dohme et al. 2001a).

Based on these in vitro observations, the objective of the present study was to evaluate in vivo the effects of the supplementation of a non-esterified MCFA on total tract $\mathrm{CH}_{4}$ emissions and digestion at varying dietary proportions of forage and $\mathrm{Ca}$. Non-esterified MCFA 14:0 was chosen since 12:0 could result in a depression of feed intake (Blaxter \& Czerkawski, 1966; Dohme et al. 2001b). The present investigation contributes knowledge useful in developing effective feeding strategies to mitigate $\mathrm{CH}_{4}$ emissions from domestic ruminants.

\footnotetext{
Abbreviations: ADF, acid-detergent fibre; MCFA, medium-chain fatty acids; NDF, neutral-detergent fibre; OM, organic matter; $\mathrm{T}_{\mathrm{d}}$, dissociation temperature; VFA, volatile fatty acids.

* Corresponding author: Dr Andrea Machmüller, fax +41 1632 1128, email andrea.machmueller@alumni.ethz.ch
} 


\section{Materials and methods}

\section{Animals and experimental design}

Castrated male sheep of the Swiss White Hill breed ( $n$ 6), aged 9 months with a mean live weight of $41 \cdot 1$ (SD 2.2) kg at the start of the experiment, were assigned to six dietary treatments in a $6 \times 6$ Latin square arrangement. In six experimental periods, each sheep received a different sequence of diets. Two basal diet types were fed, which differed in forage: concentrate value $(1: 1.5$ and $1: 0.5)$. The basal diets were calculated to cover 1.3 times maintenance requirements (Swiss Federal Research Station of Animal Production, 1999). This meant daily quantities of either $290 \mathrm{~g}$ DM of hay and $413 \mathrm{~g}$ DM of concentrate (concentrate-based diet type, Table 1) or $559 \mathrm{~g} \mathrm{DM}$ of hay and $265 \mathrm{~g}$ DM of concentrate (forage-based diet type). The meadow hay was chopped (type SS110; Gruber Maschinen $\mathrm{GmbH}$, Gaspoltshofen, Austria) to an average particle size of 67 (SD 43) $\mathrm{mm}$. The two basal diets were combined with two levels of pure non-esterified 14:0 (0 and $50 \mathrm{~g} / \mathrm{kg} \mathrm{DM})$ and two levels of dietary $\mathrm{Ca}(4.2$ and $9.0 \mathrm{~g} / \mathrm{kg} \mathrm{DM}$, the latter only in combination with the 14:0-supplemented diets). The purity of the 14:0 used was $\geq 98 \%$ (Edenor C 14 98-100; Cognis Deutschland GmbH, Düsseldorf, Germany) and the level of supplementation was the same as in the in vitro study of Dohme et al. (2001a). The proportion of dietary $\mathrm{Ca}$ was chosen to obtain a $\mathrm{Ca}: 14: 0$ molar value of either $1: 2(4.2 \mathrm{~g} \mathrm{Ca} / \mathrm{kg} \mathrm{DM})$ or $1: 1$ $(9.0 \mathrm{~g} \mathrm{Ca} / \mathrm{kg} \mathrm{DM})$. To increase the dietary $\mathrm{Ca}$ level, calcium carbonate was used. The dietary $\mathrm{Ca}$ content of $4.2 \mathrm{~g} / \mathrm{kg} \mathrm{DM}$ was within the range recommended for sheep ( 2.4 to $3.0 \mathrm{~g} \mathrm{Ca} / \mathrm{d}$; Agricultural Research Council, 1980; Swiss Federal Research Station of Animal Production, 1999). With the increased dietary Ca content of $9.0 \mathrm{~g} / \mathrm{kg} \mathrm{DM}$, the $\mathrm{Ca}: \mathrm{P}$ was $2.4: 1$ on average. The diets were offered in two equal portions at 08.00 and 16.00 hours. In each experimental period, the sheep were adapted to the respective experimental diet for $14 \mathrm{~d}$, and then subjected to $8 \mathrm{~d}$ of complete and separate collection of faeces and urine, and $2 \mathrm{~d}$ of quantitative measurement of $\mathrm{CH}_{4}$ emission in respiratory chambers. Animals were housed individually in pens $(1.3 \mathrm{~m} \times 1.9 \mathrm{~m})$ fitted with automatic drinking bowls except in the $10 \mathrm{~d}$ measurement periods, when they were kept in metabolism cages $(0.6 \mathrm{~m} \times 1.1 \mathrm{~m})$. In the cages, water troughs were filled twice daily with 5 litres fresh tap water. In the barn there was daylight and additional artificial light from 08.00 until 18.00 hours. At the end of the experiment, the mean live weight of the sheep was 49.1 (SD 1.9) kg. The experiment was carried out in accordance with Swiss guidelines for animal welfare.

\section{Sampling procedures and measurements}

The sheep were weighed before the morning feeding at the beginning of each collection period and after each respiratory measurement. Feed intake was recorded daily and refusals were removed before the next respective feeding time. Daily water consumption was measured when the animals were in the metabolism cages. Samples of hay and concentrates were collected during each experimental period. For subsequent chemical analysis, feed refusals

Table 1. Allowance and composition of the experimental diets

\begin{tabular}{|c|c|c|c|c|c|c|}
\hline \multirow[b]{2}{*}{$\begin{array}{l}\text { Myristic acid (g/kg DM)... } \\
\mathrm{Ca}(\mathrm{g} / \mathrm{kg} \mathrm{DM}) \ldots\end{array}$} & \multicolumn{3}{|c|}{$\begin{array}{l}\text { Concentrate-based diet } \\
\text { type* }\end{array}$} & \multicolumn{3}{|c|}{ Forage-based diet type* } \\
\hline & $\begin{array}{c}0 \\
4 \cdot 2\end{array}$ & $\begin{array}{l}50 \\
4 \cdot 2\end{array}$ & $\begin{array}{l}50 \\
9 \cdot 0\end{array}$ & $\begin{array}{c}0 \\
4 \cdot 2\end{array}$ & $\begin{array}{l}50 \\
4 \cdot 2\end{array}$ & $\begin{array}{l}50 \\
9 \cdot 0\end{array}$ \\
\hline \multicolumn{7}{|l|}{ Allowance (g DM/d) } \\
\hline Hay & 290 & 290 & 290 & 559 & 559 & 559 \\
\hline Concentrate & 413 & 413 & 413 & 265 & 265 & 265 \\
\hline Barley & 289 & 289 & 289 & 186 & 186 & 186 \\
\hline Soyabean meal & 124 & 124 & 124 & 80 & 80 & 80 \\
\hline Vitamin-trace element premix $\dagger$ & 3.7 & 3.7 & 3.7 & 3.7 & 3.7 & $3 \cdot 7$ \\
\hline Myristic acid & - & $35 \cdot 2$ & $35 \cdot 2$ & - & 40.9 & 40.9 \\
\hline Calcium carbonate & 1.5 & $1 . \overline{5}$ & $10 . \overline{5}$ & - & - & $10 \cdot 4$ \\
\hline \multicolumn{7}{|c|}{ Analysed nutrient composition ( $\mathrm{g} / \mathrm{kg} \mathrm{DM}$ ) } \\
\hline OM & 947 & 949 & 938 & 942 & 944 & 933 \\
\hline Crude protein $(6.25 \times N)$ & 176 & 168 & 166 & 147 & 140 & 138 \\
\hline Petrol ether extract & 21 & 61 & 60 & 19 & 59 & 58 \\
\hline \multicolumn{7}{|l|}{ Cell-wall fractions } \\
\hline NDF & 391 & 372 & 368 & 491 & 468 & 462 \\
\hline ADF & 189 & 180 & 178 & 262 & 250 & 247 \\
\hline Hemicellulose & 202 & 192 & 190 & 229 & 218 & 215 \\
\hline Non-NDF carbohydrates & 360 & 349 & 345 & 285 & 278 & 275 \\
\hline Ash & 53 & 51 & 62 & 58 & 56 & 67 \\
\hline $\mathrm{Ca}$ & 4.2 & 4.0 & 8.4 & $4 \cdot 2$ & 4.0 & 8.4 \\
\hline$P$ & 3.9 & 3.7 & 3.7 & 3.5 & $3 \cdot 3$ & $3 \cdot 3$ \\
\hline Gross energy (MJ/kg DM) & $19 \cdot 0$ & $19 \cdot 9$ & $19 \cdot 9$ & $18 \cdot 9$ & $19 \cdot 8$ & $19 \cdot 8$ \\
\hline
\end{tabular}

OM, organic matter; NDF, neutral-detergent fibre; ADF, acid-detergent fibre.

* The diet types differed in forage:concentrate. Value 1:1.5 for the concentrate-based diet type and 1:0.5 for the forage-based diet type.

†Contained (per kg) Na $100 \mathrm{~g}$; Cu $1.5 \mathrm{~g}$; Se $15 \mathrm{mg}$; lysine $5 \mathrm{~g}$; vitamin A $600 \mathrm{mg}$; vitamin $D_{3} 5 \mathrm{mg}$; vitamin $\mathrm{E}$ $2.5 \mathrm{~g}$. 
and samples of all dietary components were milled through a $0.75 \mathrm{~mm}$ screen. Complete faeces and urine were collected separately in the $8 \mathrm{~d}$ periods twice daily and stored at $-20^{\circ} \mathrm{C}$ immediately after collection. In the metabolism cages, urine was acidified by $3 \mathrm{M}-\mathrm{H}_{2} \mathrm{SO}_{4}$ to avoid $\mathrm{N}$ losses. At the end of the collection periods, proportionate samples of faeces and urine were taken and stored at $-20^{\circ} \mathrm{C}$ until chemical analysis. Part of the faeces was lyophilised for $48 \mathrm{~h}$ and milled through a $0.75 \mathrm{~mm}$ screen.

Contents of DM, ash, neutral-detergent fibre (NDF), aciddetergent fibre (ADF) and, subsequent to hydrolysis with $4 \mathrm{M}-\mathrm{HCl}$, petrol ether extract in feed and lyophilised faeces were determined according to standard methods (Naumann \& Bassler, 1997). For DM and ash, an automatic analyser was used (Thermogravimetric determinator, TGA-500; Leco Corporation, St Joseph, MI, USA). Values of NDF and $\mathrm{ADF}$ were corrected for ash content, and $\alpha$-amylase was used for NDF determination as recommended by Van Soest et al. (1991). The DM content of the urine was estimated from the urine density $(\mathrm{DM}(\mathrm{kg} / \mathrm{l})=($ density -1$) \times$ 2.6) as suggested by Hinsberg (1953). N content was measured in feed, non-lyophilised faeces and acidified urine with an automatic C/N analyser (type FP-2000; Leco Instrumente $\mathrm{GmbH}$, Kirchheim, Germany) by the Dumas method. Ca and $\mathrm{P}$ contents were determined photometrically according to standard methods (Naumann \& Bassler, 1997) using an autoanalyser (Skalar SANplus; Skalar, Breda, The Netherlands). Gross energy content of feed and lyophilised faeces was assessed by an adiabatic combustion calorimeter (C 7000 Calorimeter; IKA-Werke GmbH \& Co. KG, Staufen, Germany).

On the last day of each experimental period, rumen fluid samples were taken from each sheep $5 \mathrm{~h}$ after the morning feeding, using a flexible stomach tube inserted via the oesophagus. Immediately after collection, rumen fluid samples were strained through four layers of compress gauze (average pore size of $1000 \mu \mathrm{m}$, type 17; MedPro Novamed AG, Flawil, Switzerland). Thereafter, rumen fluid $\mathrm{pH}$ and $\mathrm{NH}_{3}$ concentration were measured using a $\mathrm{pH}$ meter (model 632; Metrohm, Herisau, Switzerland) equipped with the respective electrodes. Ciliate protozoa and bacteria were enumerated microscopically in rumen fluid samples using $0.1 \mathrm{~mm}$ and $0.02 \mathrm{~mm}$ depth Bürker counting chambers (Blau Brand ${ }^{\circledR}$, Wertheim, Germany), respectively. Holotrich and entodiniomorphid ciliate protozoa were counted separately. Samples for determination of volatile fatty acids (VFA) were stabilised with $0.046 \mathrm{M} \mathrm{mm}-\mathrm{HgCl}_{2}$ solution $\left(200 \mu \mathrm{l} / 1.8 \mathrm{ml}\right.$ rumen fluid) and frozen $\left(-20^{\circ} \mathrm{C}\right)$ until analysis. Concentrations of VFA were determined by GC using a GC Star 3400 CX (Varian, Sugarland, TX, USA) equipped with a glass column $(2 \mathrm{~m} \times 2 \mathrm{~mm}, 10 \%$ SP-1200/1\% $\mathrm{H}_{3} \mathrm{PO}_{4}$ on $80 / 100$ Chromosorb W AW, Cat. no. 11965; Supelco, Bellefonte, PA, USA) at the following conditions: $\mathrm{N}_{2}$ carrier $(30 \mathrm{ml} / \mathrm{min})$; injector temperature $250^{\circ} \mathrm{C}$; oven temperature $120^{\circ} \mathrm{C}$; detector temperature $300^{\circ} \mathrm{C}$. Rumen fluid osmolality was measured using a freezing point osmometer (Multi-Osmette; Precision Systems Inc., Natwick, MA, USA). For the enumeration of methanogens, samples of rumen fluid were frozen in liquid $\mathrm{N}_{2}$ and stored at $-70^{\circ} \mathrm{C}$. The fluorescence in situ hybridisation technique was applied in general as outlined by Stahl et al. (1995).
Cells were fixed with $4 \%(\mathrm{w} / \mathrm{v})$ sterile paraformaldehydePBS ( $\mathrm{pH} 7.2$ ) for $3 \mathrm{~h}$ at $4^{\circ} \mathrm{C}$. Mild sonication (two times for $30 \mathrm{~s}$ ) was done to avoid the formation of clusters and to optimise homogenisation of the samples (Sandaa et al. 1999). Thereafter, $3 \mu \mathrm{l}$ of the suspensions were spotted onto gelatine-coated slides, air-dried and dehydrated sequentially in 50,80 and $100 \%$ (v/v) ethanol for 3 min each. Oligonucleotide probes were purchased from Microsynth (Microsynth $\mathrm{GmbH}$, Balgach, Switzerland) with reactive fluorescent dye $\mathrm{Cy} 3$ at the $5^{\prime}$ end. The spotted slides were hybridised in $8 \mu 1$ hybridisation buffer, containing $0.1 \%$ (w/v) sodium dodecyl sulfate and $25 \mathrm{ng}$ of the respective probe. Formamide was used to standardise the hybridisation temperature at $37^{\circ} \mathrm{C}$. For $1^{\circ} \mathrm{C}$ decrease of dissociation temperature $\left(\mathrm{T}_{\mathrm{d}}\right)$ of the oligonucleotide, $2 \%(\mathrm{v} / \mathrm{v})$ formamide was added to the hybridisation buffer. After hybridisation, the slides were washed for $20 \mathrm{~min}$ at $37^{\circ} \mathrm{C}$ with the hybridisation buffer and mounted with an antifade reagent (Fluoro Guard $^{\mathrm{TM}}$; Bio Rad, Hercules, CA, USA). Labelled samples were examined with an epifluorescence microscope (BX60; Olympus Optical AG, Volketswil, Switzerland) and pictures were recorded by a 3CCD colour video camera. Individual cells were counted using image analysis software (analySIS, version 3.1; Soft Imagine System GmbH, Uster, Switzerland). Two replicates were prepared per sample, and twenty fields of view were counted per replicate. To characterise the methanogens inhabiting the rumen, five oligonucleotide probes were used as suggested by Raskin et al. (1994) and Lin et al. (1997): one domain-specific probe targeting total rumen archaea, i.e. all methanogens (S-DArch-0915-a-A-20; $\mathrm{T}_{\mathrm{d}} 56^{\circ} \mathrm{C}$ ); four order-specific probes (S-F-Mbac-0310-a-A-22 $\left(\mathrm{T}_{\mathrm{d}} 57^{\circ} \mathrm{C}\right)$ for Methanobacteriales, S-F-Mcoc-1109-a-A-20 $\left(\mathrm{T}_{\mathrm{d}} 5^{\circ} \mathrm{C}\right)$ for Methanococcales, S-O-Mmic-1200-a-A-21 $\left(\mathrm{T}_{\mathrm{d}} 53^{\circ} \mathrm{C}\right)$ for Methanomicrobiales, S-O-Msar-0860-a-A-21 ( $\left.\mathrm{T}_{\mathrm{d}} 60^{\circ} \mathrm{C}\right)$ for Methanosarcinales).

$\mathrm{CH}_{4}$ release was measured continuously with a dual chamber as elements of an open-circuit indirect respiration calorimetry system. The chambers $\left(5.44 \mathrm{~m}^{3}\right.$ volume each) were aluminium-glass constructions, allowing sight contact between sheep, and were air-conditioned (ambient temperature $17.4(\mathrm{SD} 0.5)^{\circ} \mathrm{C}$, relative humidity $60 \cdot 8(\mathrm{SD} 11 \cdot 1) \%$, air flow $8.2(\mathrm{SD} 0 \cdot 1) \mathrm{m}^{3} / \mathrm{h}$, atmospheric pressure $959(\mathrm{SD} 9) \mathrm{hPa})$. In-line electronic flow meters (type 8GD-LRM; Fluid Inventor AB, Stockholm, Sweden) continuously recorded the air volume leaving the chambers. Daily $\mathrm{CH}_{4}$ emission data were based on two consecutive days measuring $22.5 \mathrm{~h}$ each. The $\mathrm{CH}_{4}$ detector used was a Binos 1001 (Fisher-Rosemount, Baar-Walterswil, Switzerland). The detector was calibrated manually before each measurement period. Within each interval of $90 \mathrm{~min}$, one automatic calibration, four measurements of the $\mathrm{CH}_{4}$ concentrations in the air flowing into the chambers and twenty-four measurements of the $\mathrm{CH}_{4}$ concentrations in the outgoing air from each chamber were performed.

\section{Calculations and statistical analysis}

Crude protein content was calculated as $6 \cdot 25 \times \mathrm{N}$ content. Hemicellulose was computed by the difference between NDF and ADF (Van Soest et al. 1991). Non-NDF carbohydrates were defined as the organic matter $(\mathrm{OM})$ 
not incorporated in crude protein, petrol ether extract and NDF. The apparent total tract digestibility of OM and nutrients was calculated from the total dietary intake and the total excretion via faeces during the $8 \mathrm{~d}$ collection periods (intake minus excretion in relation to intake). The formula of Brouwer (1965) was used for calculation of $\mathrm{CH}_{4}$ energy loss.

Data were statistically analysed using the general linear model procedure of SAS (version 6.12; SAS Institute Inc., Cary, NC, USA). ANOVA was carried out regarding diet type ( $n$ 2), supplementation ( $n 3)$, diet type $\times$ supplementation, animal ( $n$ 6) and experimental period $(n 6)$. The tables give the mean values for the six experimental diets $(n 6)$, the overall mean values for the three supplementation groups ( $n$ 12), the standard errors of means and the $P$ values for treatment effects and the interaction. All multiple comparisons among means were performed with Tukey's studentised range post hoc test considering $P \leq 0.05$ to be significant. Pearson's correlation coefficients were calculated between rumen microbial counts. Fig. 1 gives the mean diurnal pattern of $\mathrm{CH}_{4}$ release for the six experimental diets (n 6) and, at every $4 \mathrm{~h}$, standard deviations.

\section{Results}

The different forage:concentrate values of the two basal diets resulted in differences in the analysed contents of crude protein, cell-wall fractions and non-NDF carbohydrates (Table 1). The contents of petrol ether extract and gross energy were increased with 14:0 supplementation and, likewise, the addition of calcium carbonate increased the contents of ash and $\mathrm{Ca}$.

Supplementing the basal diets with 14:0 decreased $(P<0.001)$ rumen fluid $\mathrm{pH}$ from 7.0 to 6.6 (Table 2 ). The $\mathrm{NH}_{3}$ concentration in rumen fluid was also decreased by 14:0 supplementation $(P<0 \cdot 01)$ but this effect was more pronounced in the concentrate-based diet type (interaction, $P<0 \cdot 05)$. The basal diet type and extra $\mathrm{Ca}$ had no effects on $\mathrm{pH}$ and $\mathrm{NH}_{3}$ concentration. In VFA concentrations and profile, no significant treatment interaction between diet type and supplementation occurred. Supplementing 14:0 resulted in an increase $(P<0.01)$ in the concentrations of acetate, propionate and total VFA. This was not reflected in acetate proportion but in propionate proportion $(P<0.01)$ of total VFA. Acetate: propionate was decreased $(P<0 \cdot 05$, post hoc test $)$ with 14:0 supplementation when the dietary Ca level was $4 \cdot 2 \mathrm{~g} / \mathrm{kg}$. Additionally, with 14:0 supplementation the proportions of butyrate $(P<0.001)$ and isovalerate $(P<0.01)$ were depressed. Compared with the concentrate-based diet, the foragebased diet resulted in decreased $(P<0.01)$ concentrations of total VFA, acetate, propionate and valerate $(P<0.05)$. This did not affect the molar VFA proportions. Extra $\mathrm{Ca}$

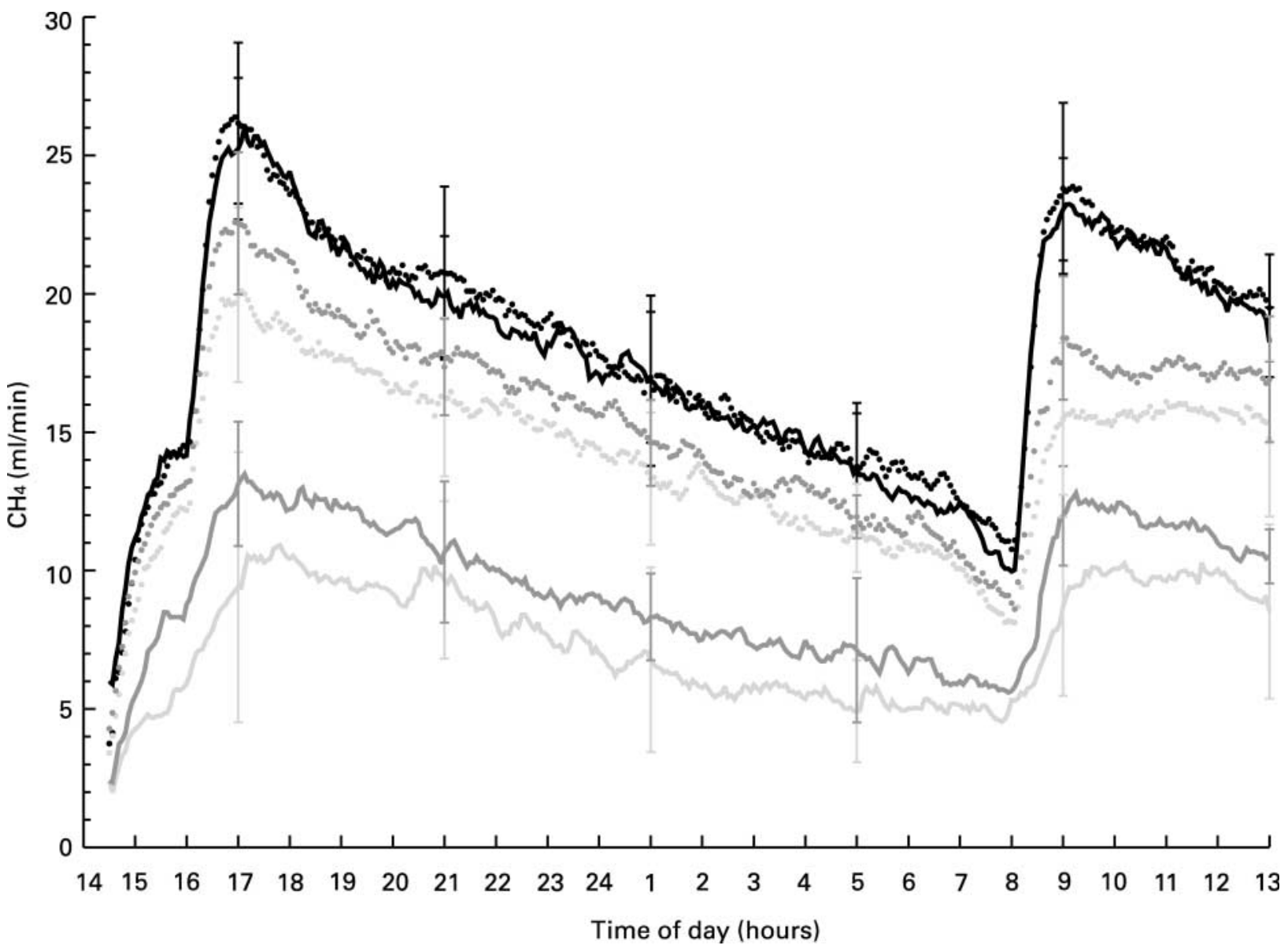

Fig. 1. Diurnal pattern of $\mathrm{CH}_{4}$ release from sheep fed either a concentrate- (-, -, -) or a forage- $(\bullet,-,-)$ based diet type combined with either $0 \mathrm{~g} 14: 0 / \mathrm{kg}$ DM and $4.2 \mathrm{~g} \mathrm{Ca} / \mathrm{kg}$ DM $(-, \bullet)$ or $50 \mathrm{~g} 14: 0 / \mathrm{kg} \mathrm{DM}$ and $4.2 \mathrm{~g} \mathrm{Ca} / \mathrm{kg} \mathrm{DM}\left(-, \bullet^{\circ}\right)$ or $50 \mathrm{~g} 14: 0 / \mathrm{kg} \mathrm{DM}$ and $9.0 \mathrm{~g} \mathrm{Ca} / \mathrm{kg} \mathrm{DM} \mathrm{(-, \bullet ).}$ The vertical bars indicate standard deviations at selected times. 


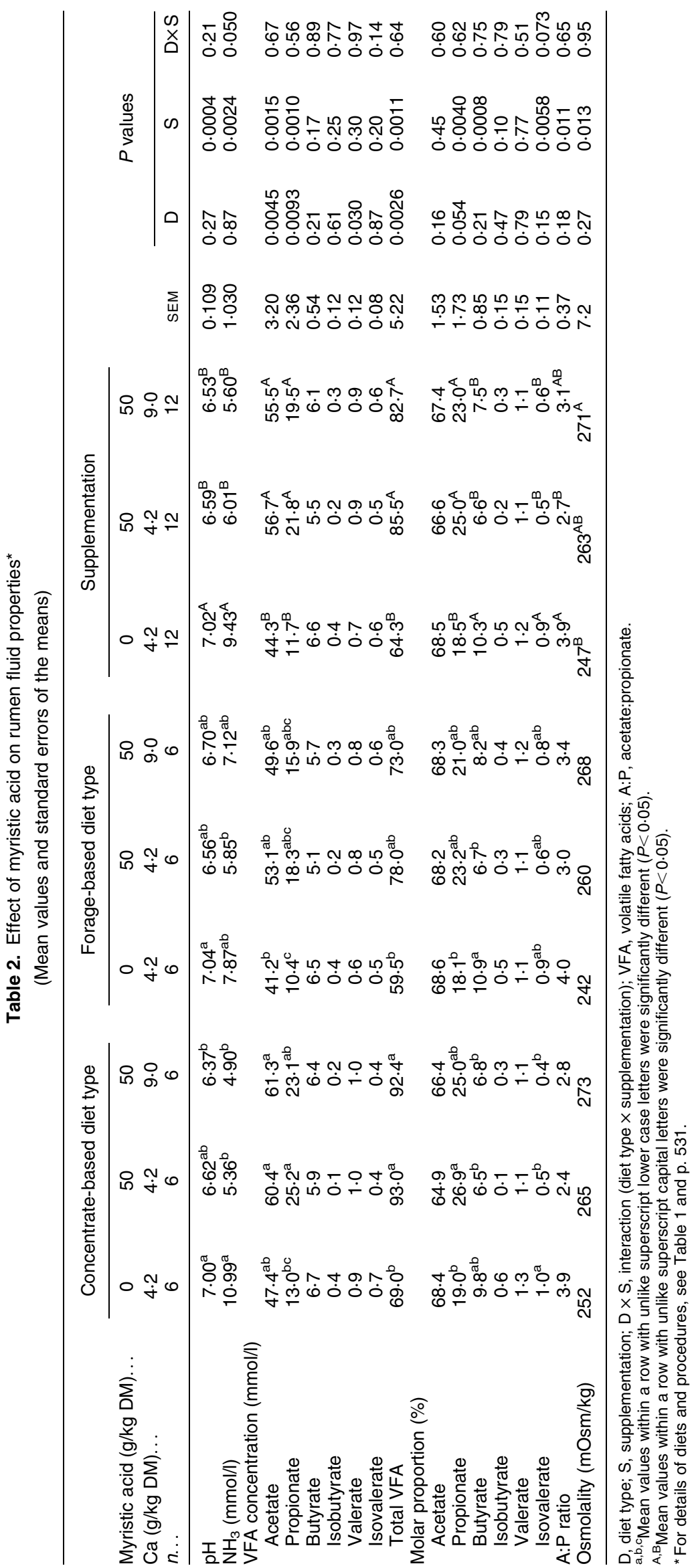


A. Machmüller et al.

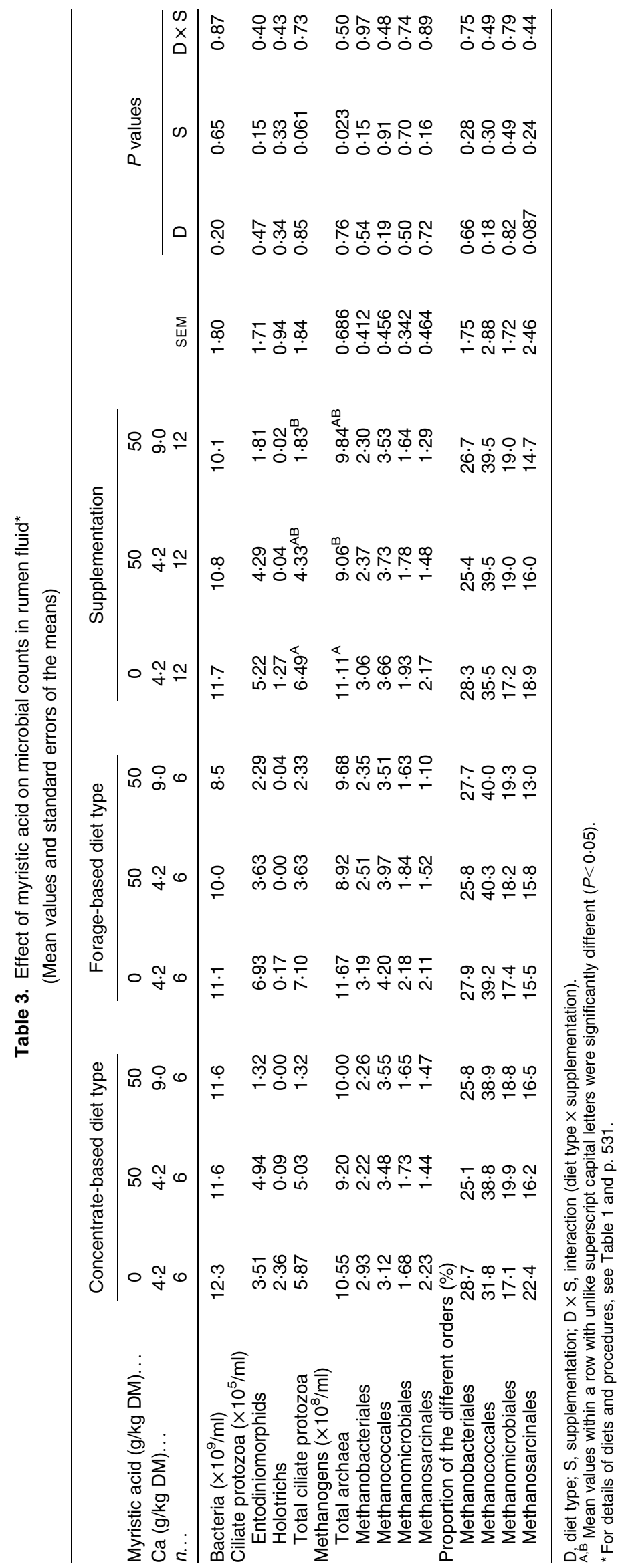


generally had little effect on VFA concentrations and profiles. The average rumen fluid osmolality was $247 \mathrm{mOsm} / \mathrm{kg}$ when feeding the basal diets and increased $(P<0 \cdot 05$, post hoc test $)$ to $271 \mathrm{mOsm} / \mathrm{kg}$ with $14: 0$ and $\mathrm{Ca}$ addition, parallel to VFA concentration.

Neither basal diet type nor supplementation significantly affected counts of bacteria, entodiniomorphid or holotrich ciliate protozoa (Table 3). On average, concentrations were $10.9 \times 10^{9} / \mathrm{ml}, 3.8 \times 10^{5} / \mathrm{ml}$ and $0.4 \times 10^{5} / \mathrm{ml}$ for bacteria, entodiniomorphid and holotrich ciliate protozoa, respectively. For total ciliate protozoa concentration, the mean value of the groups supplemented with 14:0 and extra dietary $\mathrm{Ca}$ was lower $(P<0 \cdot 05$, post hoc test $)$ than that of the unsupplemented groups. Myristic acid supplementation decreased $(P<0.05)$ archaea concentration in rumen fluid but only in combination with $4.2 \mathrm{~g} \mathrm{Ca} / \mathrm{kg}$ DM. The counts of the four individual methanogenic orders were not significantly affected by 14:0 supplementation. The basal diet type neither altered counts nor proportion of rumen methanogen orders. On average, the methanogenic population was composed of $27 \%$ Methanobacteriales, $38 \%$ Methanococcales, $18 \%$ Methanomicrobiales and $17 \%$ Methanosarcinales. The sum of the counts of the four different order-specific probes was $9.6 \times 10^{7}(\mathrm{SD} 3.3) \times 10^{7} / \mathrm{ml}$ equivalent to 97 (SD 28) $\%$ of the average counts using the Archaea domain-specific probe, illustrating that the order-specific 16S rRNA oligonucleotide probes used were appropriate to characterise the rumen methanogenic population. Counts of Methanococcales, Methanomicrobiales and Methanosarcinales were positively correlated $(P<0.05)$ with counts of entodiniomorphid ciliate protozoa (Table 4 ). The counts of total rumen archaea were positively correlated with counts of Methanobacteriales $(P<0 \cdot 05)$, Methanomicrobiales $(P<0.05)$ and Methanosarcinales $(P<0.01)$ but not with counts of Methanococcales. Accordingly, a correlation $(P<0.001)$ was found between counts of Methanobacteriales, Methanomicrobiales and Methanosarcinales. Counts of Methanococcales only were positively correlated $(P<0.01)$ with counts of Methanomicrobiales. No significant correlation occurred between total counts of bacteria and counts of the other rumen microbes.

Depending on the basal diet, the average DM intake differed among treatment groups (Table 5). Feed refusals occurred in the case of two animals ( 2 and $24 \%$ of DM allowance) when fed the concentrate-based diet type supplied with $14: 0$ at $4.2 \mathrm{~g} \mathrm{Ca} / \mathrm{kg} \mathrm{DM}$. The animals ingested 0.09 to $0.10 \mathrm{~kg}$ water/d with the feed. The intake of tap water was decreased $(P<0 \cdot 01)$ when 14:0 was supplied, especially in combination with the concentrate-based diet type (interaction, $P<0 \cdot 05$ ). The effects on water excretion via urine corresponded with the intake of tap water. The daily excreted amount of faecal water was not affected but that of faecal OM was. With the foragebased diet type, more $(P<0.001)$ OM was excreted with faeces than with the concentrate-based diet type. Independent of dietary Ca level, 14:0 supplementation increased $(P<0 \cdot 01)$ OM excretion via faeces. The total tract $\mathrm{OM}$ digestibility remained unchanged by the treatments and averaged at 0.69 . On average, the digestibilities of nonNDF carbohydrates, NDF and ADF were 0.93, 0.49 and 0.27 for the concentrate-based diet and $0.87,0.59$ and 0.52 for the forage-based diet. The 14:0 supplementation did not significantly affect digestibility of NDF and ADF, but hemicellulose digestibility was reduced $(P<0 \cdot 01)$. The effect on hemicellulose degradation was smaller with the extra $\mathrm{Ca}$ supply. The combined supplementation of $14: 0$ and $\mathrm{Ca}$ decreased $(P<0 \cdot 05$, post hoc test $)$ the digestibility of non-NDF carbohydrates, but only in the concentrate-based diet type (interaction, $P<0 \cdot 05$ ).

The two unsupplemented basal diets resulted in a similar $\mathrm{CH}_{4}$ release of about 25 litres/d. Adding $50 \mathrm{~g} 14: 0 / \mathrm{kg}$ feed $\mathrm{DM}$ to the concentrate-based diet type resulted in a significant reduction of daily $\mathrm{CH}_{4}$ release by up to $58 \%$, and this was not significantly changed by additional dietary $\mathrm{Ca}$. When the same dietary percentage of 14:0 was added to the forage-based diet type, the reduction in $\mathrm{CH}_{4}$ release was only $22 \%$ and the difference compared with the unsupplemented diet became insignificant with the increased dietary $\mathrm{Ca}$ level. The diurnal pattern of $\mathrm{CH}_{4}$ release (Fig. 1) showed that $\mathrm{CH}_{4}$ production was always similar throughout the day with the two unsupplemented basal diets. The supplementation of 14:0 decreased both the highest and lowest values measured throughout the day. Concerning the diurnal pattern, extra dietary $\mathrm{Ca}$ had similar effects in the concentrate-based and in the foragebased diet type. Relating the daily $\mathrm{CH}_{4}$ release to gross energy intake and OM digested (Table 5) further

Table 4. Relationships between rumen microbial counts ( $n$ 36)

(Pearson's correlation coefficients)

\begin{tabular}{|c|c|c|c|c|c|c|c|}
\hline & \multirow[b]{2}{*}{ Bacteria } & \multicolumn{2}{|c|}{ Ciliate protozoa } & \multicolumn{4}{|c|}{ Methanogens } \\
\hline & & ENT & $\mathrm{HOL}$ & ARC & MEB & MEC & MEM \\
\hline ENT & -0.21 & & & & & & \\
\hline $\mathrm{HOL}$ & -0.23 & 0.01 & & & & & \\
\hline ARC & 0.26 & 0.18 & -0.12 & & & & \\
\hline MEB & 0.10 & 0.32 & 0.13 & $0.34^{*}$ & & & \\
\hline MEC & -0.12 & $0.37^{*}$ & -0.15 & 0.15 & 0.22 & & \\
\hline MEM & -0.05 & $0.36^{*}$ & 0.08 & $0.35^{\star}$ & $0.65^{\star \star \star}$ & $0.50^{\star *}$ & \\
\hline MES & 0.21 & $0.36^{*}$ & 0.06 & $0.46^{\star \star}$ & $0.74^{\star \star \star}$ & 0.25 & $0.75^{\star * \star}$ \\
\hline
\end{tabular}

ENT, entodiniomorphid ciliates; HOL, holotrich ciliates; ARC, Total archaea; MEB, Methanobacteriales; MEC, Methanococcales, MEM, Methanomicrobiales; MES, Methanosarcinales.

${ }^{\star} P<0.05 ;{ }^{* \star} P<0.01 ;{ }^{* \star *} P<0.001$. 
A. Machmüller et al.

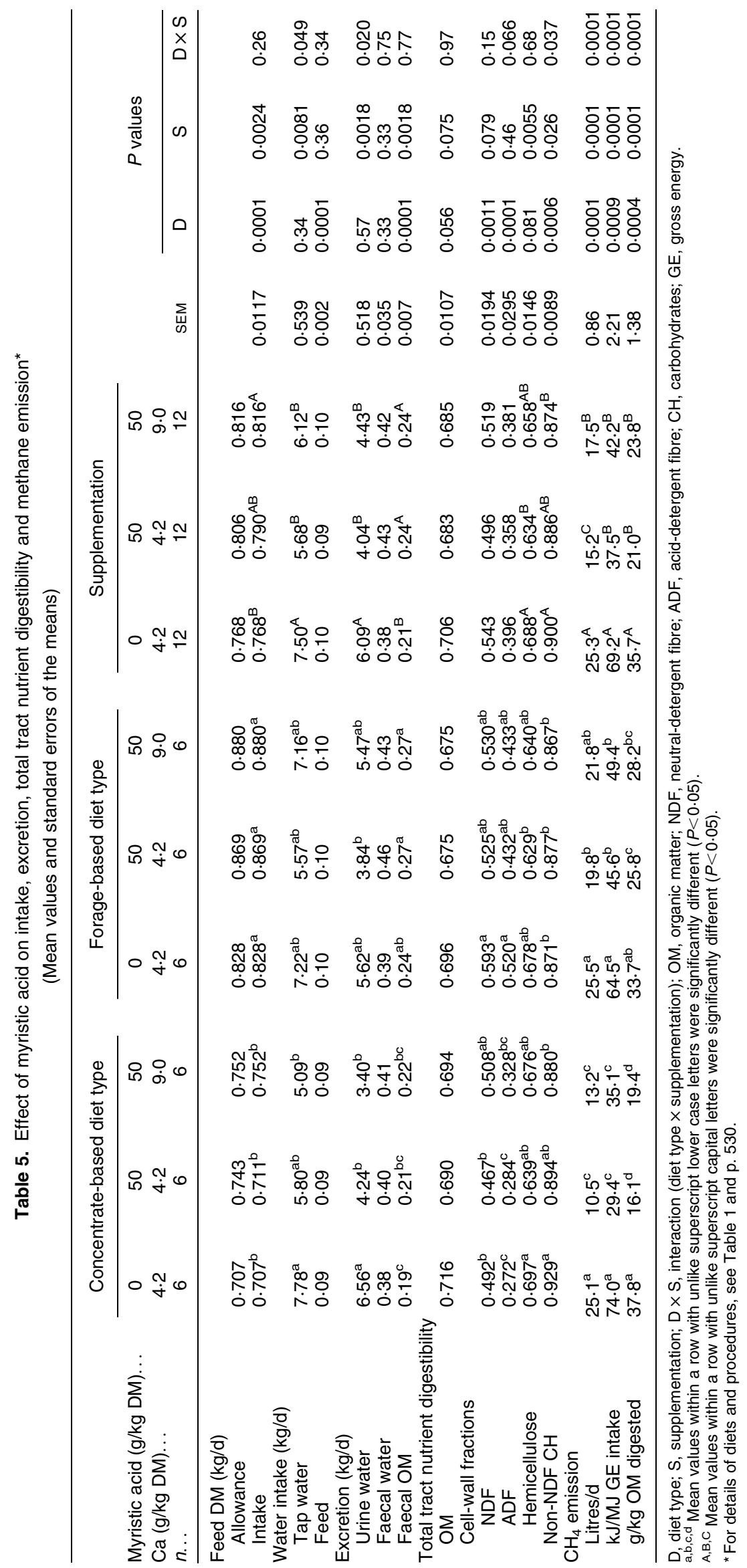


documented that the high efficacy of the 14:0 supplementation depended on the basal diet type (interaction, $P<0.001)$. The mean values for the unsupplemented basal diets were not significantly different.

\section{Discussion}

\section{Effects of the basal diet type}

Feeding strategies for ruminants, which achieve a significant $\mathrm{CH}_{4}$ suppression, are limited (Moss et al. 2000). Methanogenesis is an important terminal step in the anaerobic fermentation of OM within the rumen. Carbohydrates are the main energy source for the rumen microbes and the production of $\mathrm{CH}_{4}$ is closely related to their fermentation (Czerkawski, 1969). Compared with structural carbohydrates (for example, cellulose), it was observed that the fermentation of non-structural carbohydrates (starch, sugars) results in less $\mathrm{CH}_{4}$ per unit of substrate fermented (Hungate, 1966). Thus, increasing the dietary proportion of concentrate, i.e. the proportion of easily fermentable carbohydrates, appears to be an effective feeding strategy in decreasing rumen methanogenesis (for example, Van Nevel \& Demeyer, 1996). However, when studying the relationship between diet composition, intake level and $\mathrm{CH}_{4}$ production, Moe \& Tyrrell (1980) revealed that the nature of the carbohydrates digested (i.e. cellulose, hemicellulose or soluble residues) is less important at feed intake levels below 1.5 times maintenance. This is also supported by data of Blaxter \& Clapperton, (1965), which showed that at maintenance level, independent of the type of diet, i.e. forage or mixed diets, the percentage of gross energy converted to $\mathrm{CH}_{4}$ increases with increasing digestibility of the dietary energy. This relationship will be negative only at an intake level exceeding twice the maintenance requirements. In the present study, the feed was provided at 1.3 times maintenance requirements (Swiss Federal Research Station of Animal Production, 1999). This explains why almost equal levels of $\mathrm{CH}_{4}$ were produced per unit of apparently digested OM with both unsupplemented basal diets although the composition of the OM digested was different.

The effect of feeding level on the expression of diet type differences in $\mathrm{CH}_{4}$ release may be the result of associated changes in passage rate. Okine et al. (1989) demonstrated that the overall relationship between $\mathrm{CH}_{4}$ production and passage rate of ruminal particulate matter is negative and that ruminal passage rate explained at least $28 \%$ of the variation in $\mathrm{CH}_{4}$ production of steers. Additionally, at a low feeding level only weak effects of concentrate proportion on rumen fluid $\mathrm{pH}$ and VFA profile are expected (Zhao et al. 1993), which was confirmed by the present study. Rumen methanogenesis was shown to be a pH-dependent process (Van Kessel \& Russell, 1996). Overall, this illustrates that the $\mathrm{CH}_{4}$-suppressing effect of an increased concentrate proportion cannot be regarded as a general phenomenon.

\section{Effects of myristic acid supplementation}

In the present experiment, the 14:0 supplementation was $50 \mathrm{~g} / \mathrm{kg}$ DM, resulting in daily supplies of either 35.2 or
$40 \cdot 9 \mathrm{~g}$, depending on the basal diet type. This decreased daily $\mathrm{CH}_{4}$ emission of the animals by $40 \%$ on average. At the same time 14:0 had only small effects on total tract digestibility of $\mathrm{OM}$ and fibre. Accordingly, the greatest difference between the treatments with and without 14:0 supplementation still remained $(-41 \%)$ when $\mathrm{CH}_{4}$ release was related to the apparently digested feed OM. These effects of $14: 0$ are in line with previous results using 14:0 in vitro (Dohme et al. 2001a) or coconut oil in vivo (Machmüller \& Kreuzer, 1999). Nevertheless, with 14:0 supplementation there might have been a shift of fibre fermentation from the rumen to the hindgut as was found by Sutton et al. (1983) in sheep fed coconut oil. Since hindgut fermentation differs from rumen fermentation in producing substantially lower amounts of $\mathrm{CH}_{4}$ (Immig, 1996), this would have only marginally counteracted the suppressing effect of $14: 0$ on rumen methanogenesis.

It has been shown that the growth of rumen microbial species of all three domains of life, Archaea, Eucarya and Bacteria, could be directly affected by non-esterified MCFA. In a pure culture study, the growth of Methanobrevibacter ruminantium was found to be inhibited by adding $10: 0,12: 0$ or $14: 0$ at concentrations of $0.05,0.25$ or $0.50 \mathrm{~g} / \mathrm{l}$ medium (Henderson, 1973). Matsumoto et al. (1991) showed that rumen ciliates are suppressed by MCFA, particularly by $10: 0$ and 12:0. In an in vitro screening test some species of Gram-positive bacteria were also inhibited by MCFA, whereas Gram-negative bacteria seemed to be less sensitive (Galbraith et al. 1971). The latter indicates that probably the cell-wall structure of the microbes will determine their sensitivity against the MCFA. Kabara (1978) assumed that fatty acids inhibit microbes by affecting their lipid membranes, thus changing the permeability of the cell membrane. Among the four rumen methanogen orders there are also differences in the Gram staining. Methanobacteriales are Gram positive, Methanosarcinales are Gram variable, and Methanococcales and Methanomicrobiales are Gram negative (Boone et al. 1993).

In the present study, 14:0 supplementation significantly decreased the rumen archaeal population but showed relatively weak effects on other microbial counts. However, when 14:0 was fed, the animals significantly decreased tap water intake by $24 \%$ on average compared with the unsupplemented diet. With decreased water consumption, the expansion of rumen volume following drinking will be small (Warner \& Stacy, 1968) and the rumen fluid dilution rate will decrease (Rogers \& Davis, 1982). Therefore, in the present study, all concentrations measured in the rumen fluid have to be interpreted carefully since they may not reflect the effects on total production (Rogers \& Davis, 1982). This is not only valid for rumen microbial counts but also for the related traits concerning microbial metabolism, i.e. concentration of $\mathrm{NH}_{3}$ and VFA. Assuming a lower rumen fluid volume and a lower rumen fluid dilution rate with the 14:0 supplementation would mean that: (i) the inhibiting effect of 14:0 on archaea and ciliate protozoa was more pronounced; (ii) the decrease in total $\mathrm{NH}_{3}$ quantity was even larger; (iii) the increase in VFA production (particularly acetate and propionate) was smaller than apparent. 
In contrast, alterations in the correlation coefficients between the rumen microbial counts and in the molar proportions of VFA will not be affected by variations in water intake and rumen fluid volume. In the present study, there was no obvious relationship between counts of holotrich ciliates and methanogens, whereas counts of entodiniomorphid ciliates were positively correlated with counts of Methanococcales, Methanomicrobiales and Methanosarcinales. This presumably reflects the symbiotic relationship between rumen methanogens and ciliate protozoa (Williams \& Coleman, 1997). With the exception of the Methanococcales, all other counts of methanogen orders were significantly correlated to total archaeal counts and intercorrelated. The population of the Methanococcales might therefore actually be less sensitive to 14:0 compared with the other methanogen orders. The Methanomicrobiales seem to take an intermediate position as they were the only order showing a correlation with Methanococcales counts. Concerning the molar proportions of VFA, a lower acetate:propionate value was found with 14 : 0 supplementation. This suggests a decreased capacity of the archaea to produce $\mathrm{CH}_{4}$ as it reflects a shift from the hydrogen-consuming process of methanogenesis towards propionate production (Whitelaw et al. 1984).

As presumed additional consequences of the decreased water intake with the 14:0 supply, the average rumen $\mathrm{pH}$ was lower and the actual 14:0 concentration in the rumen fluid was higher than would have been the case without suppressed water consumption. These two aspects contributed to the high efficiency of the 14:0 supplementation against methanogenesis since they are known to increase the antimicrobial activity of 14:0 (Galbraith \& Miller, 1973; Henderson, 1973). The reduced $\mathrm{pH}$ was also accompanied by an increasing rumen osmolality (respectively osmotic pressure). The physiological mechanism that decreased water intake of the animals when consuming 14:0 is as yet unknown. To our knowledge it is the first time that such a relationship between lipid intake and ad libitum tap water intake has been described.

\section{Interactions between myristic acid supplementation and diet composition}

As mentioned earlier, the effects of $14: 0$ supplementation on rumen microbes will depend on the concentration of non-esterified fatty acids in the medium, as was shown by Henderson (1973) for the inhibition of methanogens. Galbraith et al. (1971) concluded that, to exert antimicrobial activity, non-esterified fatty acids have to be in solution and have to remain sufficiently lipophilic to permit adsorption on to the cell surface of the microbes. Therefore, dietary components that influence the concentration of free $14: 0$ in rumen fluid will be decisive for the extent of its $\mathrm{CH}_{4}$-suppressing effect. In this context, in vitro investigations with MCFA revealed two important interactions: (i) with the fibre content of the diet (Machmüller et al. 2001); (ii) with the dietary Ca content (Machmüller et al. 2002).

Harfoot et al. (1974) demonstrated that fatty acids might attach either to rumen microbes or to feed particles. Thus, for the present study two basal diets were prepared differing in their forage:concentrate value, which is associated with differences in feed particle structure and inertness. Highly significant interactions between these basal diets and supplementation were found in the $\mathrm{CH}_{4}$ emissions of the animals, which is in line with previous in vitro findings (Dong et al. 1997; Machmüller et al. 2001). In the present study, with the forage-based diet the decrease in $\mathrm{CH}_{4}$ emissions by 14:0 was less than half the decrease achieved with the concentrate-based diet. Since the two basal diets did not affect average rumen $\mathrm{pH}$, it can be assumed that this was mainly a result of the different amount and structure of the dietary particulate matter. With the forage-based diet, probably more 14:0 was attached to the feed particles and less to the methanogens than with the concentrate-based diet. The use of the forage-based diet also decreased the effects of 14 : 0 on rumen fluid $\mathrm{NH}_{3}$, water intake and water excretion, whereas other variables, such as $\mathrm{pH}$, VFA and archaeal counts, seemed to be unaffected by the combinations of basal diet type and 14:0.

In the rumen, non-esterified fatty acids could also chelate with cations, especially with the alkaline earth metal $\mathrm{Ca}$, resulting in insoluble and inactive complexes (El Hag \& Miller, 1972). The formation of Ca soaps is known to alter the effects of fatty acids on rumen fermentation (for example, Jenkins \& Palmquist, 1982). Concerning methanogenesis, significant interactions between supplementation of $12: 0$ and Ca was recorded in vitro (Machmüller et al. 2002). Accordingly, in the present study, increasing the dietary $\mathrm{Ca}$ content from 4.2 and $9.0 \mathrm{~g} / \mathrm{kg}$ DM significantly decreased the effect of the 14:0 supplementation on $\mathrm{CH}_{4}$ release from the animals and even reversed the effect of 14:0 on other traits such as rumen archaea, acetate:propionate and hemicellulose digestion. However, although the $\mathrm{Ca}: 14: 0$ molar value was increased from $1: 2$ to $1: 1$, the reversal of the $\mathrm{CH}_{4}$-suppressing effect of 14:0 was incomplete. There are three reasons why $\mathrm{Ca}$ probably had this limited effect. First, the process of saponification is directly related to rumen $\mathrm{pH}$ (Palmquist et al. 1986) with the highest rates found at a $\mathrm{pH}$ of 7 . Therefore, the decrease in $\mathrm{pH}$, which accompanied 14:0 supplementation, could have limited soap formation. Second, calcium carbonate, a common $\mathrm{Ca}$ source but known to have a low solubility in rumen fluid (Keyser et al. 1985), was used to increase the Ca content of the diets. Third, nothing is known about the $\mathrm{Ca}$ availability from the other dietary components (i.e. hay, soyabean meal and barley). However, the effect of $\mathrm{Ca}$ on methanogenesis did not differ noticeably between the two basal diets, suggesting that the $\mathrm{Ca}$ ions will interact with free 14:0 even when a proportion of $14: 0$ is inactivated by attachment to the feed particles.

\section{Conclusions}

The present results demonstrate that 14:0 is a promising feed additive to suppress $\mathrm{CH}_{4}$ emissions from ruminants, with decreases of up to $58 \%$. However, 14:0 seems to be less effective in diets with a high forage proportion, a common diet type in many agricultural systems worldwide. Concerning dietary $\mathrm{Ca}$ level, a high efficacy of $14: 0$ is guaranteed only when the Ca supply does not exceed the actual requirements of the animals. A favourable side effect of supplementing diets with 14:0 is a decreased 
water consumption, which is particularly interesting in regions with water scarcity. Generally, the present results show that, because of the impact of the animal, in vivo verifications of $\mathrm{CH}_{4}$ mitigation strategies are indispensable and that in vivo the concentrations of rumen microbes involved in methanogenesis, i.e. methanogens or ciliate protozoa, are not reliable as indicators for the success of a strategy.

\section{Acknowledgements}

The authors gratefully acknowledge the technical assistance of R. H. Razminowicz and S. J. Dulęba in animal care and laboratory analysis and acknowledge B. Jörg for technical support in matters concerning the respiratory chambers.

\section{References}

Agricultural Research Council (1980) The Nutrient Requirements of Ruminant Livestock. Slough, UK: Commonwealth Agricultural Bureaux.

Blaxter KL \& Clapperton JL (1965) Prediction of the amount of methane produced by ruminants. $\mathrm{Br} J$ Nutr $\mathbf{1 9}$ $511-522$.

Blaxter KL \& Czerkawski J (1966) Modifications of the methane production of the sheep by supplementation of its diet. $J$ Sci Food Agric 17, 417-421.

Boone DR, Whitman WB \& Rovière P (1993) Diversity and taxonomy of methanogens. In Methanogenesis: Ecology, Physiology, Biochemistry \& Genetics, pp. 35-80 [JG Ferry, editor]. New York, NY: Chapman \& Hall.

Brouwer E (1965) Report of sub-committee on constants and factors. In Energy Metabolism, pp. 441-443 [KL Blaxter, editor]. London: Academic Press.

Czerkawski JW (1969) Methane production in ruminants and its significance. In World Review of Nutrition and Dietetics, vol. 11, pp. 240-282 [GH Bourne, editor]. Basel, Switzerland: $\mathrm{S}$ Karger.

Dohme F, Machmüller A, Wasserfallen A \& Kreuzer M (2001a) Ruminal methanogenesis as influenced by individual fatty acids supplemented to complete ruminant diets. Lett Appl Microbiol 32, 47-51.

Dohme F, Sutter F, Machmüller A \& Kreuzer M (2001b) Methane formation and energy metabolism of lactating cows receiving individual medium-chain fatty acids. In Energy Metabolism in Animals. Proceedings of the 15th Symposium on Energy Metabolism in Animals, 2000, pp. 369-372 [A Chwalibog and $\mathrm{K}$ Jabobsen, editors]. Wageningen, The Netherlands: Wageningen Pers.

Dong Y, Bae HD, McAllister TA, Mathison GW \& Cheng KJ (1997) Lipid-induced depression of methane production and digestibility in the artificial rumen system (RUSITEC). Can J Anim Sci 77, 269-278.

El Hag GA \& Miller TB (1972) Evaluation of whisky distillery by-products VI. The reduction in digestibility of malt distiller's grains by fatty acids and the interaction with calcium and other reversal agents. J Sci Food Agric 23, 247-258.

Galbraith H \& Miller TB (1973) Effect of metal cations and pH on the antibacterial activity and uptake of long chain fatty acids. J Appl Bacteriol 36, 635-646.

Galbraith H, Miller TB, Paton AM \& Thompson JK (1971) Antibacterial activity of long chain fatty acids and the reversal with calcium, magnesium, ergocalciferol and cholesterol. $J$ Appl Bacteriol 34, 803-813.

Harfoot CG, Crouchman ML, Noble RC \& Moore JH (1974) Competition between food particles and rumen bacteria in the uptake of long chain fatty acids and triglycerides. J Appl Bacteriol 37, 633-641.

Henderson C (1973) The effects of fatty acids on pure cultures of rumen bacteria. J Agric Sci 81, 107-112.

Hinsberg K (1953) Untersuchung der Organe, Körperflüssigkeiten und Ausscheidungen. 2. Harn. (Investigation of the organs, body fluids and excreta 2. Urine). In Handbuch der Physiologisch- und Pathologisch-chemischen Analyse, 10th ed., vol. 5, pp. 181-300 [K Lang and E Lehnnartz, editors]. Berlin, Germany: Springer-Verlag.

Hungate RE (1966) The Rumen and its Microbes. New York, NY: Academic Press Inc.

Immig I (1996) The rumen and hindgut as source of ruminant methanogenesis. Environ Monit Assess 42, 57-72.

Jenkins TC \& Palmquist DL (1982) Effect of added fat and calcium on in vitro formation of insoluble fatty acid soaps and cell wall digestibility. $J$ Anim Sci 55, 957-963.

Johnson DE, Johnson KA, Ward GM \& Branine ME (2000) Ruminants and other animals. In Atmospheric Methane: Its Role in the Global Environment, pp. 112-133 [MAK Khalil, editor]. Berlin, Germany: Springer-Verlag.

Kabara JJ (1978) Fatty acids and derivatives as antimicrobial agents. A review. In The Pharmacological Effect of Lipids, pp. 1-14 [JJ Kabara, editor]. Champaign, IL: The American Oil Chemists' Society.

Keyser RB, Noller CH, Wheeler LJ \& Schaefer DM (1985) Characterization of limestones and their effects in vitro and in vivo in dairy cattle. J Dairy Sci 68, 1376-1389.

Khalil MAK (2000) Atmospheric methane: an introduction. In Atmospheric Methane: Its Role in the Global Environment, pp. 1-8 [MAK Khalil, editor]. Berlin, Germany: SpringerVerlag.

Lin C, Raskin L \& Stahl DA (1997) Microbial community structure in gastrointestinal tracts of domestic animals: comparative analyses using rRNA-targeted oligonucleotide probes. FEMS Microbiol Ecol 22, 281-294.

Machmüller A, Dohme F, Soliva CR, Wanner M \& Kreuzer M (2001) Diet composition affects the level of ruminal methane suppression by medium-chain fatty acids. Aust J Agric Res 52, 713-722.

Machmüller A \& Kreuzer M (1999) Methane suppression by coconut oil and associated effects on nutrient and energy balance in sheep. Can J Anim Sci 79, 65-72.

Machmüller A, Soliva CR \& Kreuzer M (2002) In vitro ruminal methane suppression by lauric acid as influenced by dietary calcium. Can J Anim Sci 82, 233-239.

Matsumoto M, Kobayashi T, Takenaka A \& Itabashi H (1991) Defaunation effects of medium-chain fatty acids and their derivatives on goat rumen protozoa. J Gen Appl Microbiol 37, 439-445.

Moe PW \& Tyrrell HF (1980) Methane production in dairy cows. In Energy Metabolism. Proceedings of the 8th Symposium on Energy Metabolism, 1979, pp. 59-62 [LE Mount, editor]. London: Butterworths.

Moss AR, Jouany JP \& Newbold J (2000) Methane production by ruminants: its contribution to global warming. Annal Zootech 49, 231-253.

Naumann K \& Bassler R (1997) Methodenbuch. Band III. Die Chemische Untersuchung von Futtermitteln, 4th ed. Darmstadt, Germany: VDLUFA-Verlag.

Okine EK, Mathison GW \& Hardin RT (1989) Effects of changes in frequency of reticular contractions on fluid 
and particulate passage rates in cattle. J Anim Sci 67, 3388-3396.

Palmquist DL, Jenkins TC \& Joyner AE Jr (1986) Effect of dietary fat and calcium source on insoluble soap formation in the rumen. J Dairy Sci 69, 1020-1025.

Raskin L, Stromley JM, Rittmann BE \& Stahl DA (1994) Groupspecific 16S rRNA hybridization probes to describe natural communities of methanogens. Appl Environ Microbiol 60, $1232-1240$.

Rogers JA \& Davis CL (1982) Rumen volatile fatty acid production and nutrient utilization in steers fed a diet supplemented with sodium bicarbonate and monensin. $J$ Dairy Sci 65, 944-952.

Sandaa RA, Enger $\varnothing$ \& Torsvik V (1999) Abundance and diversity of Archaea in heavy-metal-contaminated soils. Appl Environ Microbiol 65, 3293-3297.

Stahl DA, Amann RI, Poulsen LK, Raskin L \& Capman WC (1995) Use of fluorescent probes for determinative microscopy of methanogenic Archaea. In Archaea: Methanogens: A Laboratory Manual, pp. 111-121 [KR Sowers and HJ Schreier, editors]. New York, NY: Cold Spring Harbor Laboratory Press.

Sutton JD, Knight R, McAllan AB \& Smith RH (1983) Digestion and synthesis in the rumen of sheep given diets supplemented with free and protected oils. Br J Nutr 49, 419-432.

Swiss Federal Research Station of Animal Production (1999) Fütterungsempfehlungen und Nährwerttabellen für Wiederkäuer, 4th ed. Zollikofen, Switzerland: Landwirtschaftliche Lehrmittelzentrale.

Van Kessel JAS \& Russell JB (1996) The effect of pH on ruminal methanogenesis. FEMS Microbiol Ecol 20, 205-210.

Van Nevel CJ \& Demeyer DI (1996) Control of rumen methanogenesis. Environ Monit Assess 42, 73-97.

Van Soest PJ, Robertson JB \& Lewis BA (1991) Methods for dietary fiber, neutral detergent fiber, and nonstarch polysaccharides in relation to animal nutrition. $J$ Dairy Sci $\mathbf{7 4}$, 3583-3597.

Warner ACI \& Stacy BD (1968) The fate of water in the rumen 2. Water balances throughout the feeding cycle in sheep. $\mathrm{Br} J$ Nutr 22, 389-410.

Whitelaw FG, Eadie JM, Bruce LA \& Shand WJ (1984) Methane formation in faunated and ciliate-free cattle and its relationship with rumen volatile fatty acid productions. $\mathrm{Br} J$ Nutr $\mathbf{5 2}$, 261-275.

Williams AG \& Coleman GS (1997) The rumen protozoa. In The Rumen Microbial Ecosystem, pp. 73-139 [PN Hobson and CS Stewart, editors]. London: Chapman \& Hall.

Wuebbles DJ \& Hayhoe K (2002) Atmospheric methane and global change. Earth-Sci Rev 57, 117-210.

Zhao JY, Shimojo M \& Goto I (1993) The effects of feeding level and roughage/concentrate ratio on the measurement of protein degradability of two tropical forages in the rumen of goats, using the nylon bag technique. Anim Feed Sci Technol 41, $261-269$. 